\title{
Zinc Deficiency: Effect on Brain of the Suckling Rat
}

\author{
Harold H. Sandstead, ${ }^{[38]}$ David D. Gillespie, and Robert N. Brady \\ Division of Nutrition and Department of Biochemistry, Vanderbilt University, Nashville, Tennessee, USA
}

\begin{abstract}
Extract
The effect of zinc deficiency on the brain of the suckling rat was studied by feeding a zinc-deficient $\left(\mathrm{Zn}^{-}\right)$diet to dams from parturition and measuring the in vivo uptake of ${ }^{3} \mathrm{H}$-thymidine by brain DNA and the ${ }^{35} \mathrm{~S}$ uptake by brain protein as well as the brain lipid composition of their pups. These results were compared with similar data obtained on pups nursed by pair-fed (PF) and ad libitum-fed control dams which had been given zinc in addition to the diet.

The specific activities (SA) of DNA and protein were decreased in the brains and livers of the pups nursed by the zinc-deficient dams compared with pups nursed by dams pair-fed with the zinc-deficient dams and hence semistarved (SA of brain DNA: $\mathrm{Zn}^{-}=5.90$ versus $\mathrm{PF}=11.36 ; \mathrm{SA}$ of liver DNA: $\mathrm{Zn}^{-}=5.16$ versus $\mathrm{PF}=15.8 ; \mathrm{SA}$ of brain protein: $\mathrm{Zn}^{-}=50.20$ versus $\mathrm{PF}=85.30 ; \mathrm{SA}$ of liver protein: $\mathrm{Zn}^{-}=56.02$ versus $\mathrm{PF}=79.20$ ). On the other hand, similar concentrations of DNA, RNA, and protein were present in their brains as well as their livers. The concentrations of total lipid were decreased in the brains of the deficient pups compared with the controls $\left(\mathrm{Zn}^{-}=\right.$ 0.215 versus $\mathrm{PF}=0.309 \mathrm{mg} / \mathrm{mg}$ of brain), while the concentrations of brain phospholipid and the brain fatty acid patterns were similar.

Zinc deficiency has thus been shown to impair DNA and protein synthesis in brain of the suckling rat as it has previously been shown to do in other tissues including liver and epiphyseal plate.
\end{abstract}

\section{Speculation}

Zinc is essential for synthesis of nucleic acids and protein. In individuals with proteincalorie malnutrition, an associated zinc deficiency may compound the effects of protein deprivation by impairing utilization of the limited protein available. Zinc deficiency in the human may thus contribute to the impaired brain growth reported to occur in infants with protein-calorie malnutrition.

\section{Introduction}

Zinc is an essential nutrient for higher animals. It is a constituent of many metalloenzymes [19] and has an incompletely understood role in mammalian protein metabolism $[12,13,15]$ and nucleic acid synthesis [16, $22,30]$. Zinc-deficient animals show growth retardation and delayed sexual maturation [1] as well as impaired wound healing [24]. Zinc deficiency during pregnancy causes a high incidence of abortion [23] and teratology in the rat [14]. Maternal zinc deprivation has been shown to impair DNA synthesis in the fetal rat brain [30]. Retarded human growth and sexual maturation [25] have also been found to respond to treatment with zinc in some instances, as has impaired wound healing [20]. Nucleic acid and protein synthesis are fundamental to all of these processes. 
The apparent interrelation of zinc nutriture to protein nutriture implied by the above experimental observations and clinical findings in protein-calorie deficient man, which suggest that zinc deficiency sometimes is associated with protein-calorie malnutrition $[21,26]$, prompted the work that we are reporting. Protein-calorie malnutrition in infants [35], severe undernutrition in rodents $[4,9]$, and maternal protein deficiency in rats [36] result in impaired brain growth and decreased total brain DNA when the deficiency occurs during the critical period for brain growth. We wonder whether zinc deficiency occurring in conjunction with protein deficiency, as may occur in the human infant, may compound the effect of protein and calorie deprivation by interfering with utilization of the meager dietary protein available.

To examine this hypothetical interrelation, the effects of maternal zinc deficiency were compared with the effects of maternal pair feeding (semistarvation) on the brains of their suckling pups.

\section{Methods}

Dams of the Charles River strain were fed a biotin-enriched $20 \%$ sprayed egg white diet, containing $<0.5$ ppm zinc [22], from the time of parturition. They were housed with 6 of their litter in zinc-free plastic cages with perforated bottoms and given glass-distilled drinking water. The room environment was controlled for light, temperature, humidity, and dust.

The dams were divided into three groups: (a) zincdeficient, (b) pair-fed controls (fed the amount of food eaten by the zinc-deficient dams on the previous day)



Fig. 1. Effect of zinc deficiency on growth rate of nursing rat pups. The rate of gain of the deficient pups decreased on the 3rd day. injected with $100 \mu \mathrm{g}$ zinc daily, and (c) ad libitum-fed controls, also injected daily with $100 \mu \mathrm{g}$ zinc. The use of pair-fed control dams was particularly important in this study because, as is also true of other deficiency syndromes, zinc deficiency results in a striking anorexia in the animal fed the zinc-deficient diet. Hence, the zinc-deficient animal is subjected not only to deficiency of the essential cation, but also to semistarvation resulting from anorexia. Preliminary studies were done to determine the effect of maternal zinc deprivation during lactation on the growth of the suckling pups. It was found that zinc deprivation during lactation inhibited the rate of growth of pups to a greater degree than did maternal semistarvation (pair-feeding). Pups from representative litters were selected for the following study.

Each pup was injected intraperitoneally with a trace amount of ${ }^{3} \mathrm{H}$-thymidine and carrier-free $\mathrm{Na}_{2}{ }^{35} \mathrm{SO}_{4}$ on the 1lth day of life. Twenty-four hours later it was killed by decapitation and its brain, liver, and thymus gland were weighed, frozen in liquid nitrogen, freezedried, and stored at $-140^{\circ} \mathrm{F}$.

The dried brain and liver were crushed to a fine powder and a portion was homogenized in ice-cold $5 \%$ trichloroacetic acid with a glass homogenizer. Fat was removed by three extractions with a methanol-diethyl ether-chloroform $(2: 2: 1)$ solution. The fat-free trichloroacetic acid precipitate was dried and stored until the DNA [8, 34], RNA [33], and protein [17] contents were measured. The specific activity of the DNA and protein was determined by liquid scintillation counting of the respective extracts.

The remaining dried brain was extracted four times with chloroform-methanol $(2: 1)$, and the total lipid [5] and lipid phosphorus $(3,10)$ were determined. Cerebellums from other pups of the same age were extracted four times with chloroform-methanol and evaporated to dryness. The residue was suspended in $1 \%$ methanolic sulfuric acid and transesterified [10]. The resulting fatty acid methyl esters were characterized by gas chromatography on a $10 \%$ diethylene-glycol succinate column.

\section{Results}

The growth rate of the zinc-deficient pups was retarded compared with the pair-fed (semistarved) and ad libitum pups. Figure 1 shows this finding on representative litters. After the 3rd day of zinc deprivation the rate of gain of pups nursed by the zinc-deficient dam decreased while the pups nursed by the pair-fed 
(semistarved) dam continued to gain. Zinc-deficient pups showed no gain from the 8 th to the 12th day. The severity of the growth retardation which occurred is illustrated by Figure 2. The zinc-deficient pup is roughly half as large as the ad libitum pup. Abnormalities in its coat, not seen in either pair-fed or ad libitum pups, are evident on the back of its head. When photographed, it did not exhibit exploratory behavior, it seemed ataxic, and, as shown in Figure 2, fell over on its haunches. Pups nursed by pair-fed dams (not shown in the picture) were also quite small, compared with the ad libitum pups as indicated by Figure 1 .

The question of quality and quantity of milk produced by the pair-fed and zinc-deficient dams was not explored. Presumably, pair feeding resulted in a decreased quantity of milk produced. This would account for growth failure of the pups nursed by the pair-fed dams. In the case of pups nursed by the zincdeficient dams, not only was the quantity of milk presumably decreased, but its quality was presumably changed; i.e., its zinc content was decreased. Thus the pups nursed by the zinc-deficient dam were doubly deprived. The difference between their growth pattern and that of the pups nursed by pair-fed dams supports this supposition.

The organ weights were proportionate to the body weights (milligram per gram) with the exception that the thymus glands of zinc-deficient pups were smaller than those of the pair-fed pups $(2.5 \mathrm{mg} / \mathrm{g}$ body weight versus $3.4 \mathrm{mg} / \mathrm{g}$ body weight). Weights of the thymus glands of the pair-fed pups were similar to those of the ad libitum pups (milligram per gram body weight).

Analysis of the trichloroacetic acid precipitates of the brains and livers for DNA, RNA, and protein revealed similar concentrations of these components in the respective organs of all three groups. The total content of DNA related to organ size, a finding similar to that of Guthrie and Brown [9] in rats malnourished during the nursing period. Because our findings were in general agreement with those of Guthrie and Brown [9] and did not suggest that either zinc deficiency or starvation caused gross alterations in tissue composition (in terms of concentration) at this age, except for total lipid, the individual data on protein, $\mathrm{DNA}$, and RNA are not presented.

Lipid composition of brain was altered by both pair feeding and zinc deficiency in the dams. The concentrations of total lipid were less in the brains of the zinc-deficient pups compared with the pair-fed animals $(P<0.05)$. An even greater difference was present between the pair-fed pups and the ad libitum pups $(P$

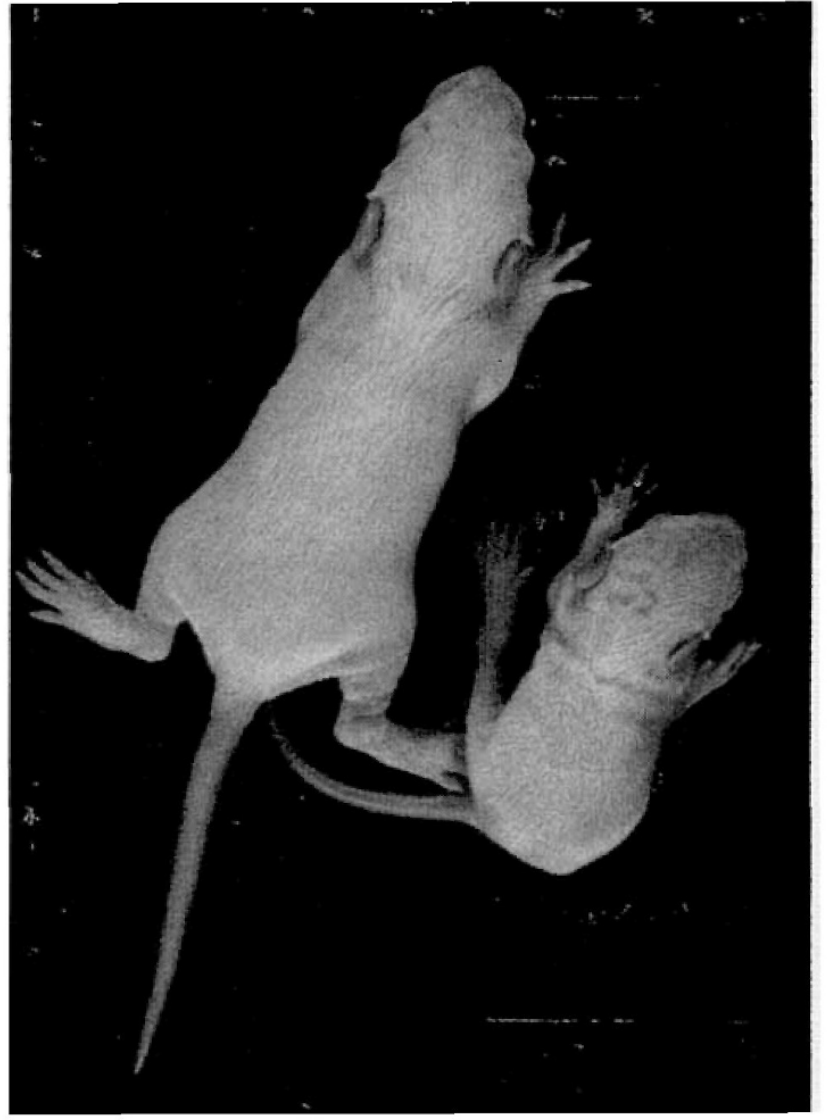

Fig. 2. Effect of maternal zinc deficiency on growth of the nursing pup. The larger pup was nursed for 12 days by a zinc-adequate ad libitum-fed dam, while the smaller was nursed for 12 days by a zinc-deficient dam.

$<0.001$ ) (Table I, Fig. 3). In spite of this difference in total lipid concentrations, the concentrations of brain lipid phosphorus were similar in all three groups and zinc-deficient pups had the greatest concentration of lipid phosphorus per milligram total lipid. It appears that the alteration in total lipid concentration was not due to a specific abnormality in lipid metabolism, as gas chromatography of cerebellar fatty acids revealed no differences in the fatty acid composition between the three groups. The specific activity of the brain and liver DNA of the zinc-deficient pups was less than in the pair-fed animals (Table I, Fig. 3$)(P<0.01)$, as was the specific activity of the protein from these two organs $(P<0.00 \mathrm{l})$, implying that their net synthesis was depressed by zinc deficiency. On the other hand, the brain DNA and protein of the ad libitum pups contained less ${ }^{3} \mathrm{H}$-thymidine and ${ }^{35} \mathrm{~S}$, respectively, than those of the pair-fed pups $(P<0.01)$, while in contrast, the specific activity of liver DNA was similar between 
Table $I$. Effect of zinc deficiency on specific activities of brain and liver DNA and protein, and the lipid content of brain

\begin{tabular}{|c|c|c|c|c|c|c|}
\hline & No. & Experimental group & $\bar{x}$ & $s$ & SE & $P$ \\
\hline $\begin{array}{l}\text { Specific activity of brain DNA, } \\
\mathrm{cpm} / \mathrm{mg} \text { deoxyribose }\end{array}$ & 6 & Pair-fed & 11.36 & 3.447 & 1.542 & $<0.01$ \\
\hline \multirow{3}{*}{$\begin{array}{l}\text { Specific activity of liver DNA, } \\
\mathrm{cpm} / \mathrm{mg} \text { deoxyribose }\end{array}$} & 5 & Zinc-deficient & 5.16 & 1.744 & 0.872 & $<0.001$ \\
\hline & 11 & Pair-fed & 15.18 & 5.179 & 1.638 & NS 1 \\
\hline & 6 & Ad libitum-fed & 20.22 & 5.605 & 2.507 & \\
\hline \multirow{2}{*}{$\begin{array}{l}\text { Specific activity of brain protein, } \\
\mathrm{cpm} / \mathrm{mg}\end{array}$} & 6 & Pair-fed & 85.30 & 10.828 & 4.842 & $<0.001$ \\
\hline & 5 & Ad libitum-fed & 47.96 & 3.576 & 1.788 & \\
\hline \multirow{3}{*}{$\begin{array}{l}\text { Specific activity of liver protein, } \\
\mathrm{cpm} / \mathrm{mg}\end{array}$} & 5 & Zinc-deficient & 56.02 & 8.166 & 4.083 & $<0.01$ \\
\hline & 11 & Pair-fed & 79.20 & 18.743 & 5.927 & $<0.001$ \\
\hline & 6 & Ad libitum-fed & 46.75 & 4.485 & 2.005 & \\
\hline \multirow[t]{3}{*}{$\mu \mathrm{g} \mathrm{P} / \mathrm{mg}$ lipid } & 3 & Zinc-deficient & 39.867 & 5.873 & 4.153 & $<0.05$ \\
\hline & 3 & Pair-fed & 25.467 & 1.250 & 0.884 & $<0.001$ \\
\hline & 3 & Ad libitum-fed & 10.833 & 0.818 & 0.578 & \\
\hline \multirow[t]{3}{*}{$\mu \mathrm{g}$ lipid $\mathrm{P} / \mathrm{mg}$ brain } & 3 & Zinc-deficient & 8.498 & 0.633 & 0.448 & NS \\
\hline & 3 & Pair-fed & 7.925 & 0.735 & 0.520 & NS \\
\hline & 3 & Ad libitum-fed & 8.592 & 1.063 & 0.752 & \\
\hline
\end{tabular}

1 NS : not significant.

these two groups. Liver protein of the ad libitum pups contained less ${ }^{35} \mathrm{~S}$ than did that of the pair-fed controls (Table I).

To relate the specific activity of brain DNA to the level of brain maturation, as reflected by the total lipid concentration, the specific activities were multiplied by their respective lipid concentrations. By this criterion of maturation, the brains of the zinc-deficient pups incorporated the least ${ }^{3} \mathrm{H}$-thymidine, the brains of the pair-fed pups were intermediate, and those of the ad libitum-fed animals incorporated the most (1.27 versus 3.51 versus 4.29 ). It is of interest that the adjusted specific activities of brain DNA relate to one another in a manner similar to the way in which the findings for liver DNA specific activity relate to one another (Table I).

\section{Discussion}

It appears from this study that zinc deficiency during the early neonatal period of the rat will impair growth of the brain, as assessed by the incorporation of thymidine into DNA, sulfur into protein, and the total lipid concentration. From studies on food utilization of weanling zinc-deficient rats, it seems likely that zinc-deficient suckling pups utilize mother's milk less efficiently than do pups nursed by pair-fed (semistarved) dams. More detailed studies to clarify this issue should be done. In any case, for conceptual purposes, zinc-deficient pups seem to be protein-deficient at the cellular level, zinc deficiency having an additive effect on the consequences of protein and calorie deprivation as observed in the pups nursed by the pair-fed dams and previously described with more elegant experiments by others $[4,9,36]$.

Brain maturation is reflected in part by its lipid concentration [7]. Brains of the pups from ad libitumfed mothers were more mature by this criterion than were the brains of zinc-deficient pups. Lipid synthesis in the developing rat brain may be retarded by protein and calorie deprivation [4,9], an effect produced by pair feeding lactating dams. Zinc deficiency appears to have caused a further retardation in total lipid synthesis in the brain without altering its fatty acid composition.

The rate of synthesis of DNA in the neonatal rat brain declines by the 12th neonatal day. At about the same time the lipid concentration of the brain increases rapidly. The specific activity of the brain DNA and the 
lipid concentration of the brains of the ad libitum pups were consistent with these dynamic changes in the rate of cell division and lipid synthesis which take place at this time. The pair-fed and zinc-deficient pups demonstrated delayed brain maturation as judged by lipid concentration, and were thus still in the phase of brain growth when increased cell division takes place. While the pair-fed pups demonstrated that they were indeed in the developmental stage of more rapid cell division by having a greater specific activity of brain DNA than the ad libitum pups, the zinc-deficient pups, although roughly at the same stage of brain development in terms of brain lipid concentration, had a lower specific activity of brain DNA than the pups of the pair-fed dams. This finding is consistent with the observations of Swenerton et al. [30] in fetal zinc-deficient rats, and is supported by our previous studies on the effects of zinc deficiency on DNA synthesis of the weanling rat liver [22]. In the present study, the effect of zinc deficiency and pair feeding on the incorporation of thymidine into the DNA of the livers of these pups also supports our interpretation of the findings in the brain.

The decrease in sulfur incorporation into protein in the zinc-deficient pups was consistent with the observations of Hsu et al. [12, 13], who have shown that zinc deficiency suppresses the in vivo incorporation of methionine and increases the catabolism of cystine and methionine and the excretion of inorganic sulfate in the rat. Of interest was the increase in liver protein specific activity in the pair-fed pups, compared with the ad libitum pups. We suspect that this is a reflection of an increased polysome formation and protein synthesis in the pair-fed animals, similar to that described by Shaw and Follios [28] and postulated to be a compensatory phenomenon. The zinc-deficient animals appeared unable to respond to this stress. Recent studies in our laboratory consistent with an abnormality in polysome formation in zinc deficiency [27] may also help to explain these findings.

The mechanism by which zinc deficiency retards protein synthesis is unknown. The studies cited above [27] on liver polysomes and the observations by Tal [31] on ethylenediaminetetraacetic acid-treated Escherichia coli ribosomes suggest that zinc is essential for ribosomal function, possibly as a stabilizer of tertiary structure. The intimate association of zinc to RNA recently shown by Holt et al. [11] and previously suggested by Wacker and Vallee [32] is supportive of this concept. A second and by no means exclusive possibility is that zinc is necessary for synthesis of RNA.

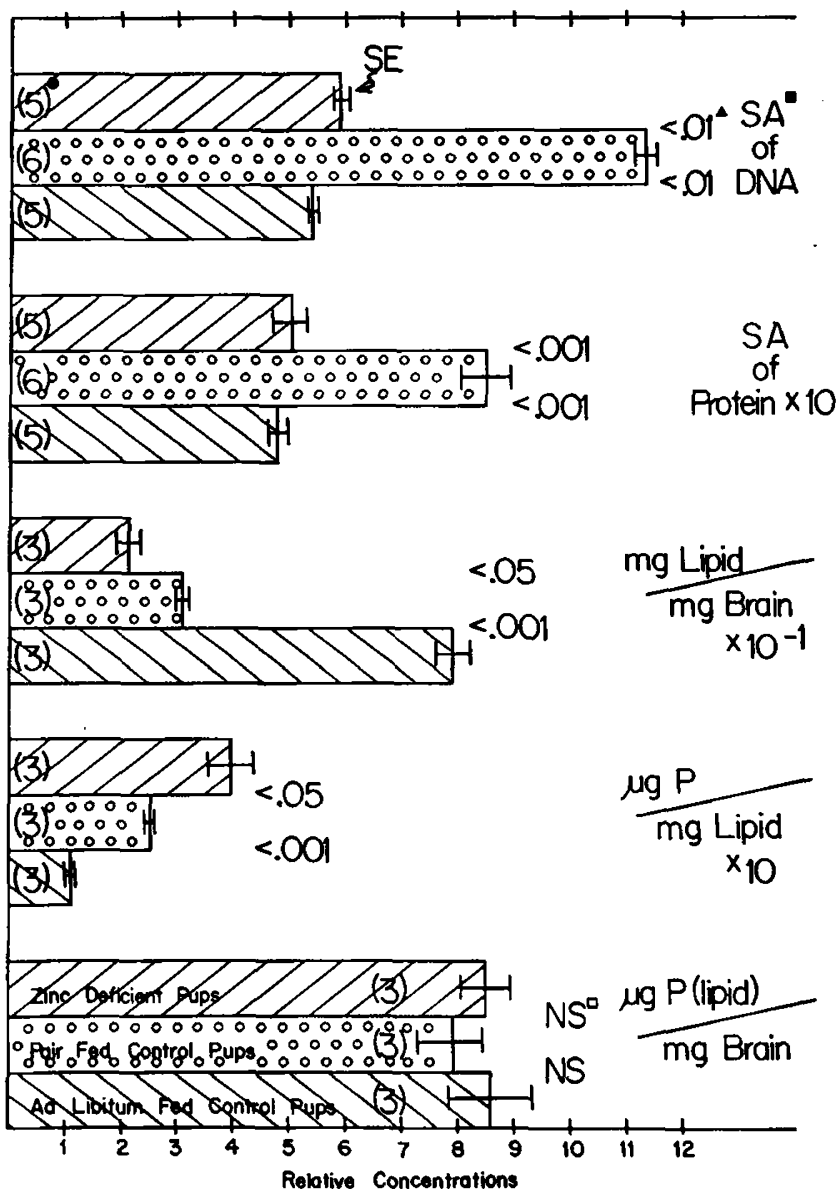

Fig. 3. Effect of maternal zinc deficiency on specific activity of brain DNA ( ${ }^{8} \mathrm{H}$-thymidine), protein $\left({ }^{25} \mathrm{~S}\right)$, lipid, and lipid phosphorus concentrations and phosphorus/lipid ratio. As indicated at the bottom of the figure, bars cross-hatched to the right: zinc-deficient. Bars with circles: pair-fed controls. Bars crosshatched to the left: ad libitum-fed controls. $\Delta: P$ value. $\square$ : specific activity. $\square$ : not significant.

Studies by Terhune [27] indicate that the activity of liver nuclear DNA-dependent RNA polymerase is suppressed by zinc deficiency in the suckling rat. This effect of zinc deficiency may be analogous to the suppression of DNA polymerase and thymidine kinase activity in zinc-deficient tissue culture [6]. To our knowledge, it is not known whether RNA polymerase is a zinc metalloenzyme or whether decreased activity of the enzyme is a reflection of decreased synthesis of the enzyme. In any case, it seems possible that synthesis of certain species of RNA may be decreased owing to decreased activity of RNA polymerase. A third role of zinc in RNA metabolism may be one of protection of ribosomes from ribonuclease by stabilization of the molecule and perhaps by obstructing the active site on 
which ribonuclease acts. Macapinlac et al. [18] presented evidence consistent with an increased rate of RNA and protein degradation in the zinc-deficient rat testis, and Somers and Underwood [29] have found increased ribonuclease activity in zinc-deficient testis. Both of these studies support the concept that zinc may protect the active site on RNA or modify its tertiary structure so that it is not susceptible to ribonuclease.

Speculative application of these laboratory studies to human disease, however tenuous, is appropriate. Because concentrations of plasma zinc consistent with deficiency are found in protein-calorie malnutrition [21, $26]$, it is reasonable to suggest that lack of zinc may compound the severity of protein-calorie malnutrition through impairment of protein utilization. It has been suggested but not unequivocally demonstrated that protein-calorie malnutrition impairs subsequent behavioral development in human infants. We suggest that zinc deficiency may contribute to this phenomenon. In this light, it is of interest that Caldwell et al. [2] have reported that zinc deficiency early in the life of the rat will impair its behavioral development in a manner not unlike protein deficiency.

\section{Summary}

Suckling rats nursed by zinc-deficient dams have been shown to have impaired incorporation of thymidine into brain and liver DNA. Incorporation of sulfur into protein of these two organs is also decreased. Zinc deficiency also resulted in a decrease in concentration of total lipid in brain while phospholipid concentration and fatty acid patterns were unaffected.

\section{Addenda}

Since this manuscript was submitted for publication, a paper was presented at the 1971 meeting of the American Institute of Nutrition regarding the quality and quantity of milk from zinc-deficient, pair-fed and ad libitum-fed lactating dams. The quantity of milk is apparently decreased by pair feeding, while the protein and zinc concentrations of the milk are increased. The zinc concentration of milk from zinc-deficient dams is strikingly decreased (Mutch, P. B., and Hurley, L. S.: Zinc deficiency in suckling rats (Abstract). Fed. Proc. 30: 2501(1971)).

A paper which appeared after this manuscript was accepted for publication reports that RNA polymerase of $E$. coli is a zinc metalloenzyme (Scrutton, M. C., Wu, C. W., and Goldwait, D. A.: The presence and possible role of zinc in RNA polymerase obtained from Escherichia coli. Proc. Nat. Acad. Sci. U. S. A., 68: 2497 (1971)).

\section{References and Notes}

1. Barney, G. H., Orgebin-Crist, M. C., and Macapinlac, M. P.: Genesis of esophageal parakeratosis and histologic changes in the testes of the zinc deficient rat and their reversal by zinc repletion. J. Nutr., 95: 526 (1968).

2. Caldwell, D. F., Oberteeas, D., Clancy, J. J., and Prasad, A. S.: Behavioral impairment in adult rats following acute zinc deficiency. Proc. Soc. Exp. Biol. Med., 133: 1417 (1970).

3. Chen, P. S., Jr., Toribara, T. Y., and Warner, H.: Microdetermination of phosphorus. Anal. Chem., 28: 1756 (1956).

4. Culley, W. J., ANd Lineberger, R. O.: Effect of undernutrition on the size and composition of the rat brain. J. Nutr., 96: 375 (1968).

5. Folch, J., Lees, M., and Sloane-Stanlex, G. H.: A simple method for the isolation and purification of total lipids from animal tissues. J. Biol. Chem., 226: 497 (1957).

6. Fujroka, M., AND LIEBerman, I.: A zinc requirement for synthesis of deoxyribonucleic acid in rat liver. J. Biol. Chem., 239: 1164 (1964).

7. Gerson, R. L., AND WAISMAN, H. H.: Effects of nutritional status on rat brain maturation as measured by lipid composition. J. Nutr., 100: 315 (1970).

8. Giles, K. W., and Meyers, A.: An improved diphenylamine method for the estimation of deoxyribonucleic acid. Nature, 206: 93 (1965).

9. Guthrie, H. A., AND Brown, M. L.: Effect of severe undernutrition in early life on growth, brain size and composition in adult rats. J. Nutr., 94: 419 (1968).

10. Haskell, B. E., and Snell, E. E.: Effect of vitamin $B_{6}$ deficiency on the composition of yeast lipids. Arch. Biochem. Biophys., 112: 494 (1965).

11. Holt, A. B., Mellits, E. D., AND CheeK, D. B.: Comparisons between nucleic acids, protein, zinc, and manganese in rat liver: a relation between zinc and ribonucleic acid. Pediat. Res., 4: 157 (1970).

12. Hsu, J. M., AND Anthony, W. L.: Zinc deficiency and urinary excretion of taurine- ${ }^{35} \mathrm{~S}$ and inorganic sulfate- ${ }^{-35} \mathrm{~S}$ following cystine- ${ }^{35}$ S injection in rats. J. Nutr., 100: 1189 (1970).

13. Hsu, J. M., Anthony, W. L., and Buchanan, P. J.: Zinc deficiency and incorporation of ${ }^{24} \mathrm{C}$-labeled methionine into tissue proteins in rats. J. Nutr., $99: 425$ (1969).

14. Hurley, L. S.: Zinc deficiency in the developing rat. Fed. Proc., 22: 1332 (1969).

15. Lema, O., and Sandstead, H. H.: Zinc deficiency: effect on epiphyseal growth. Clin. Res., 18: 458 (1970).

16. Lieberman, I., Abrams, R., Hunt, N., ANo Ove, P.: Levels of enzyme activity and deoxyribonucleic acid synthesis in mammalian cells cultured from the animal. J. Biol. Chem., 238: 3955 (1963).

17. Lowry, O. H., Rosebrough, N. J., Farr, A. L., and Randall, R. J.: Protein measurement with the Folin phenol reagent. J. Biol. Chem., 193: 265 (1951).

18. Macapinlac, M. P., Pearson, W. N., Barney, G. A., and DARBY, W. J.: Protein and nucleic acid metabolism in the testes of zinc deficient rats. J. Nutr., 95: 569 (1968). 
19. Parisi, A. F., ANo Vallee, B. L.: Metalloenzymes: characteristics and significance in biology of medicine. Amer. J. Clin. Nutr., 22: 1222 (1969).

20. Pories, W. H., Henzel, J. H., Rob, C. G., and Strain, W. H.: Acceleration of healing with zinc sulfate. Ann. Suirg., 165: 432 (1967).

21. Prasad, A. S., Miale, A., Jr., Farid, Z., Sandstead, H. H., Schulert, A. R., AND Darby, W. J.: Biochemical studies on dwarfism, hypogonadism, and anemia. Arch. Intern. Med., 111: 407 (1963).

22. SANDSTEAD, H. H., AND RINALdI, R.: Impairment of deoxyribonucleic acid synthesis by dietary zinc deficiency in the rat. J. Cell. Physiol., 73: 81 (1969).

23. Sandstead, H. H., Glasser, S. R., and Gillespie, D. D.: Zinc deficiency: effect on fetal growth, zinc concentration and ${ }^{85}$ zinc uptake (Abstract). Fed. Proc., 29: 297 (1970).

24. Sandstead, H. H., Lanier, V. G., Shiepard, G. H., ANd Gillespie, D. D.: Zinc and wound healing: effects of zinc deficiency and zinc supplementation. Amer. J. Clin. Nutr., 23: 514 (1970).

25. Sandstead, H. H., Prasad, A. S., Schulert, A. R., Farid, Z., Miale, A., Bassilly, S., AND Darby, W. J.: Human zinc deficiency, endocrine manifestations and response to treatment. Amer. J. Clin. Nutr., 20: 422 (1967).

26. Sandstead, H. H., Shukry, A. S., Prasad, A. S., Gabr, M. K., El Hufney, A., Mokhtar, N., and Darby, W. J.: Kwashiorkor in Egypt. Amer. J. Clin. Nutr., 17: 15 (1965).

27. Sandstead, H. H., Terhune, M., Brady, R. N., Gillespie, D., AND Holloway, W. L.: Zinc deficiency: brain DNA, protein and lipids and liver ribosomes and RNA polymerase. Clin. Res., 19: 83 (1971).

28. Shaw, C., AND Follios, L. C.: RNA polymerase activities and other aspects of hepatic protein synthesis during early protein depletion in the rat. J. Nutr., 96: 327 (1968).

29. Somers, M., AND UNDERWood, E. J.: Ribonuclease activity and nucleic acid and protein metabolism in the testes of zinc deficient rats. Aust. J. Biol. Sci., 22: 1277 (1969).

30. Swenerton, H., Shrader, R., and Hurley, L. S.: Zinc deficient embryos: reduced thymidine incorporation. Science, 166: 1014 (1969).

31. TAL, M.: Metal ions and ribosomal conformation. Biochem. Biophys. Acta, 195: 76 (1969).

32. Wacker, W. E. C., and Vallee, B. L.: Nucleic acids and metals. J. Biol. Chem., 234: 3257 (1959).

33. WeBb, J. M.: A sensitive method for the determination of ribonucleic acid in tissues and microorganisms. J. Biol. Chem., 221: 635 (1956).

34. WebB, J. M., And Lindstrom, H. V.: Acid solubilization of animal tissue nucleic acids as related to their extraction and estimation. Arch. Biochem. Biophys., 112: 273 (1965).

35. WinIcK, M.: Malnutrition and brain development. J. Pediat., 74: 667 (1969).

36. Zeman, F. J., and Stanbough, E. C.: Effect of maternal starvation and protein deficiencies on cellular development in the fetal rat. J. Nutr., 99: 274 (1969).

37. Supported by Nutrition Foundation Grants nos. 397 and 430, Public Health Service Research Grants nos. AM-05441 and 1504-FR-06067, and Biomedical Support Grant no. 7351 to the John F. Kennedy Center for Research on Education and Human Development.

38. Requests for reprints should be addressed to: Harold $\mathbf{H}$. SANDSTEAD, M.D., USDA Human Nutrition Laboratory, Grand Forks, N. D. 58201 (USA).

39. Accepted for publication May 20, 1971. 